\title{
The effect of distinct operational conditions on organic material removal and biogas production in the anaerobic treatment of cattle manure
}

\author{
Neslihan Manav Demir, Tamer Coşkun, Eyüp Debik \\ Yildiz Technical University, Environmental Engineering Department, Istanbul, Turkey \\ * Corresponding author. Tel: +90 212 3835369, Fax: +90 212 3835358, E-mail: debik@yildiz.edu.tr
}

\begin{abstract}
Although very difficult to treat due to their complicated composition, the increasing amounts of cattle manure generation makes their purification a compulsory task for environmental engineers to prevent their adverse environmental impacts. Historically, these wastes have been used as a fuel or a soil fertilizer. The generation of cattle manure even in increasing amounts in Turkey, however, makes this kind of use unfeasible. Therefore, new methods to dispose of these wastes are required. This study focuses on the anaerobic digestion process for the treatment of cattle manure. In the study, two lab-scale anaerobic reactors were employed to investigate the effects of different operating temperatures $\left(35^{\circ} \mathrm{C}\right.$ and $\left.55^{\circ} \mathrm{C}\right)$, of different total suspended solids concentrations (\%5 and 10\%), of different hydraulic retention times (20 days and 40 days), and of the addition of corn silage on the treatment performance. The performance of the reactor was evaluated with respect to total solids (TS), volatile solids (VS) and biogas production. The results of the study suggested that the thermophilic reactor showed a good treatment performance (59\% VS removal and $0.29 \mathrm{~L}$ methane per VS added) when the cattle manure of $10 \%$ solids content together with corn silage were fed. Besides, it was concluded that the addition of corn silage to the reactors improved the treatment efficiencies and that the addition of irrigational organic materials increases biogas production rate. The results of the study point out that anaerobic digestion process is a viable option for cattle manure stabilization and valuable gas production.
\end{abstract}

Keywords: Anaerobic Digestion, Cattle Manure, Biogas, Methane

\section{Nomenclature}

TS total solids

VS volatile solids

HRT hydraulic retention times $m g \cdot k g^{-1}$ $m g \cdot \mathrm{kg}^{-1}$

day
TOC total organic carbon

COD chemical oxygen demand.....

cfu colony forming unit.

\section{Introduction}

The number of cattles have shown an increasing trend in Turkey. In 2007, the capacity of cattles in Turkey reached over 11 millions [1]. This increase, unfortunately, led to an increase in the environmental problems caused by inappropriate disposal of cattle manures into the environment, due to which the proper treatment of these wastes gained attraction in last years. Current disposal methods (burning and using as fertilizer) have proven to be inadequate and research is ongoing for new treatment methods.

Cattle manure can be as harmful as other industrial wastes in environmental aspects. Therefore, development of new treatment methods for the safe disposal of these wastes would prevent endangering the public health. Besides, the end product of the anaerobic digestion process could easily be used as an organic fertilizer and this use would contribute to sustainable development strategies.

In addition to the severe environmental impacts caused by the uncontrolled disposal of cattle manure, possible future energy crisis makes the environmental engineers to provide solutions both economically and environmentally sound. Production of energy through biomass along with a by-product that can be used as a natural fertilizer are the major advantages of this process. 
Although being a very complicated process, anaerobic digestion simply involves three stages as (1) the conversion of high-density organic materials into low-density materials by hydrolysis, (2) the conversion of low-density organics into acetate by acid bacteria, and (3) methane production by methane bacteria by consuming acetate, carbon dioxide and hydrogen [2]. Coskun et al. (2009) listed the factors affecting the anaerobic digestion of cattle manure as (1) solids content and hydraulic retention time, (2) $\mathrm{pH}$ and alkalinity, (3) trace elements and nutrients, (4) temperature, (5) toxic content of the waste, (6) $\mathrm{C} / \mathrm{N}$ ratio, and (7) dilution ratio of the waste [3].

This study aims at the evaluation of anaerobic digestion alternatives for cattle manure treatment with differing hydraulic retention times, feed contents and feed solids contents. The investigation involved the determination of the most feasible anaerobic digestion method for the treatment of cattle manure in Turkey.

\section{Methodology}

\subsection{Characterization of cattle manure}

Cattle manure contains insoluble organic materials as well as soluble organics such as polysaccharides, fats, and volatile fatty acids. Their high chemical oxygen demand (COD), ammonia and phosphorous content make them very complicated and extremely difficult to treat [4]. The cattle manure used in this study was obtained from Gebze District of Kocaeli of Turkey and the characteristics of the waste are given in Table 1.

Table 1. General characteristics of the raw cattle manure (Gebze-Kocaeli)

\begin{tabular}{ccc}
\hline Parameter & Unit & Value \\
\hline pH & - & 7.41 \\
Moisture & $\%$ & 80.98 \\
Volatile solids (VS) & $\%$ & 73.58 \\
Ash & $\%$ & 5.12 \\
$\mathrm{C}$ & $\%$ & 39.12 \\
$\mathrm{~N}$ & $\%$ & 1.35 \\
$\mathrm{C}: \mathrm{N}$ & - & 28.94 \\
$\mathrm{P}$ & $\%$ & 0.96 \\
$\mathrm{H}$ & $\%$ & 5.01 \\
$\mathrm{~S}$ & $\%$ & 0.40 \\
\hline
\end{tabular}

\subsection{Measurement methods}

TS, VS, total organic carbon (TOC), biogas production and methane content of the biogas were continuously monitored during the study. For TS and VS, the method "DS/EN 12879 Characterization of sludges" was followed. TOC analyses were conducted using Hach-Lange IL 550 TOC/TN device. TOC analyses were conducted in the effluents from the reactors starting from the sixth week of the study. The biogas production was measured daily via a Ritter Drum-type gasmeter and LMSx Multigas Analyser was used to assess the biogas composition. Salmonella spp. was measured according to "ISO 6579/April, 1996 Salmonella measurement methods" while "NF-ISO 166492 (June 2001) Horizontal method for the enumeration of glucuronidase-positive Escherichia coli $\beta$ - Part 2: Technique of colony count at $44{ }^{\circ} \mathrm{C}$ by means of 5-bromo-4-chloro-3-indolyl- $\beta$-D-glucuronate acid (IC: V08-031-2)” was used for E.coli measurement. 


\subsection{Experimental setup}

Two lab-scale, completely mixed, stainless-steel, cylindrical anaerobic reactors with $10 \mathrm{~L}$ of active volumes were operated at $35{ }^{\circ} \mathrm{C}$ and $55{ }^{\circ} \mathrm{C}$, simultaneously, for the treatment of cattle manure. The solids contents of $5 \%$ and $10 \%$ along with the hydraulic retention times of 20 days and 40 days were used during the study. Solids content of the manure was set to $5 \%$ or $10 \%$ with tap water before feeding. Further, mixtures of cattle manure and corn silage were fed to determine the effects of the use of a supplementary organic material. The reactor performances were evaluated with respect to TS, VS, Salmonella spp., and E.coli removal efficiencies as well as biogas production rate. The experimental setup is shown in Figure 1.

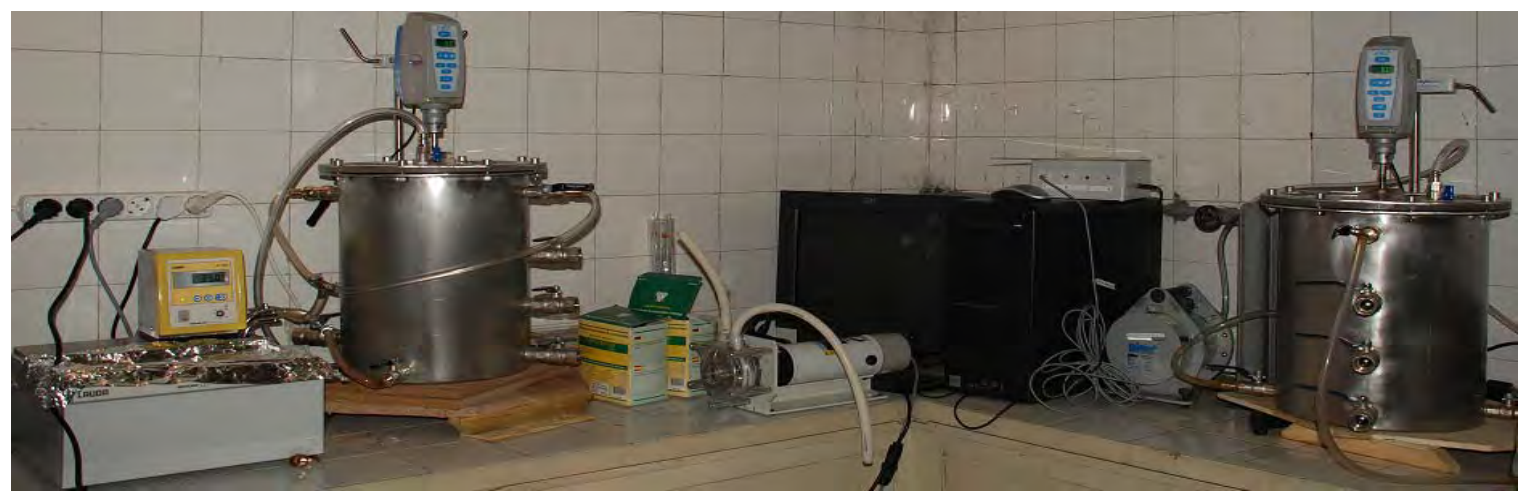

Fig. 1. Lab-scale anaerobic treatment system [3].

\section{Results}

\subsection{Cattle manure feed at $5 \%$ solids content}

First of all, the reactors were fed with only cattle manure of $5 \%$ solids content and were operated at 20 days of hydraulic retention time (HRT) at $35{ }^{\circ} \mathrm{C}$ (mesophilic range) and $55^{\circ} \mathrm{C}$ (thermophilic range), respectively. After 10 weeks of successful operation, the retention times were increased to 40 days. Figure 2 shows the change of TS, VS and TOC when only cattle manure of $5 \%$ solids content was fed to the reactors.

The TS concentration in the effluent of mesophilic reactor at HRT=20 days changed between 39,000 and $43,000 \mathrm{mg} / \mathrm{kg}$ while values of same range were obtained in the effluent of thermophilic reactor. The TS removal efficiency of the mesophilic reactor was calculated between $14 \%$ and $21 \%$ while that of thermophilic one ranged between $10 \%$ to $21 \%$. After increasing the HRT to 40 days, the TS content of the effluents were increased first and then decreased to $31,000 \mathrm{mg} / \mathrm{kg}$ for mesophilic reactor and 32,000 mg/kg for thermophilic one in $16^{\text {th }}$ week. At the end of the study, the TS removal efficiencies reached to about $38 \%$ and $36 \%$ for mesophilic and thermophilic reactors, respectively. The reason for the TS removal efficiency to drop first when the HRT was increased from 20 days to 40 days is the reaction of microorganisms to the changing environmental conditions [3].

During the study, VS concentration of the waste was determined to be $38,800 \mathrm{mg} / \mathrm{kg}$. For HRT $=20$ days, effluent VS concentrations ranged from 27,000 to $30,000 \mathrm{mg} / \mathrm{kg}$ and from 28,000 to $31,000 \mathrm{mg} / \mathrm{kg}$ for mesophilic and thermophilic reactors, respectively. The VS removal efficiencies ranged from $23 \%$ to $30 \%$ and from $20 \%$ to $29 \%$, respectively. After increasing the HRT to 40 days, the effluent VS concentrations increased first and decreased to around $23,000 \mathrm{mg} / \mathrm{kg}$ for both reactors. At the end of the study, the VS removal efficiencies were about $41 \%$ for both reactors. 
TOC concentration of the waste was measured as approximately between 15,600 and 19,900 $\mathrm{mg} / \mathrm{kg}$. For HRT=20 days, average effluent TOC concentrations were around 11,700 mg/kg and $12,300 \mathrm{mg} / \mathrm{kg}$ for mesophilic and thermophilic reactors, respectively. After increasing the HRT to 40 days, average effluent TOC concentrations were increased to about 12,000 and $13,300 \mathrm{mg} / \mathrm{kg}$, respectively. The effluent TOC concentrations averaged over the whole study were 11,900 and $13,000 \mathrm{mg} / \mathrm{kg}$ for mesophilic and thermophilic reactors, respectively, and average TOC removal efficiencies of the reactors were calculated as $32.8 \%$ and $25.4 \%$, respectively.



Fig. 2. TS, VS and TOC concentrations in the effluents from mesophilic (A) and thermophilic (B) reactors when only cattle manure of $5 \%$ solids content was fed.

Starting with the second week of the study, biogas production rate showed an increasing trend for both reactors. However, the rate was decreased after increasing the HRT. The biogas production rate was measured as between 0.10 and $0.34 \mathrm{~L}_{\text {biogas }} / \mathrm{gVS}_{\text {added, }}$ and between 0.15 and $0.41 \mathrm{~L}_{\text {biogas }} / \mathrm{gVS}_{\text {added }}$ for mesophilic and thermophilic reactors according to the HRTs of 20 days and 40 days, respectively. During the whole study, methane content of the biogas was between $45 \%$ and $55 \%$ for both reactors. Therefore, the methane production rates for mesophilic and thermophilic reactors ranged from 0.06 to $0.19 \mathrm{~L}_{\text {methane }} / \mathrm{gVS}_{\text {added }}$ and from 0.08 to $0.23 \mathrm{~L}_{\text {methane }} / \mathrm{gVS}_{\text {added, }}$ respectively.

Salmonella spp. was not detected in both effluents during the whole study. For thermophilic reactor, E. coli was determined to be $10 \mathrm{cfu} / \mathrm{kg}$ while this value reached up to $1,000 \mathrm{cfu} / \mathrm{kg}$ for mesophilic one. The results showed that the mesophilic range of operating temperature (35 ${ }^{\circ} \mathrm{C}$ ) was less effective in E.coli removal while they are completely removed in thermophilic temperature $\left(55^{\circ} \mathrm{C}\right)$. 


\subsection{Cattle manure feed at $10 \%$ solids content}

In this stage of the study, the solids content of the raw waste was increased to $10 \%$ and the reactors were operated at HRT of 40 days. Average concentrations of TS, VS, and TOC in the raw waste were determined to be $100,000 \mathrm{mg} / \mathrm{kg}, 82,400 \mathrm{mg} / \mathrm{kg}$, and $36,400 \mathrm{mg} / \mathrm{kg}$, respectively. The results of TS, VS, and TOC analyses in the effluents are shown in Figure 3. For mesophilic reactor, TS, VS, and TOC removal efficiencies were around 20.3\%, 23.8\%, and $21.3 \%$, respectively. The removal efficiencies for the thermophilic reactor were calculated as $24.9 \%, 28.3 \%$, and $22.1 \%$, respectively.

In this stage, the mesophilic and thermophilic reactors produced 0.12 to $0.23 \mathrm{~L}_{\text {biogas }} / \mathrm{gVS}_{\text {added }}$ and 0.16 to $0.32 \mathrm{~L}_{\text {biogas }} / \mathrm{gVS}_{\text {added }}$ of biogas, respectively. The methane production rates were measured as between 1.17 to $2.16 \mathrm{~L} /$ day and 1.47 to $2.89 \mathrm{~L} /$ day, respectively. In terms of VS fed to the reactors, mesophilic reactor produced 0.06 to $0.10 \mathrm{~L}$ methane per $\mathrm{gVS}_{\text {added }}$ while the rate for thermophilic one was measured as between 0.08 and $0.14 \mathrm{~L}_{\text {methane }} / \mathrm{gVS}_{\text {added. }}$.

In the aspect of Salmonella spp. removal, both reactors produced perfect effluents. However, this was not the same for E.coli. E.coli was not detected in the effluent from the thermophilic reactor while the mesophilic one was less effective in E.coli removal.

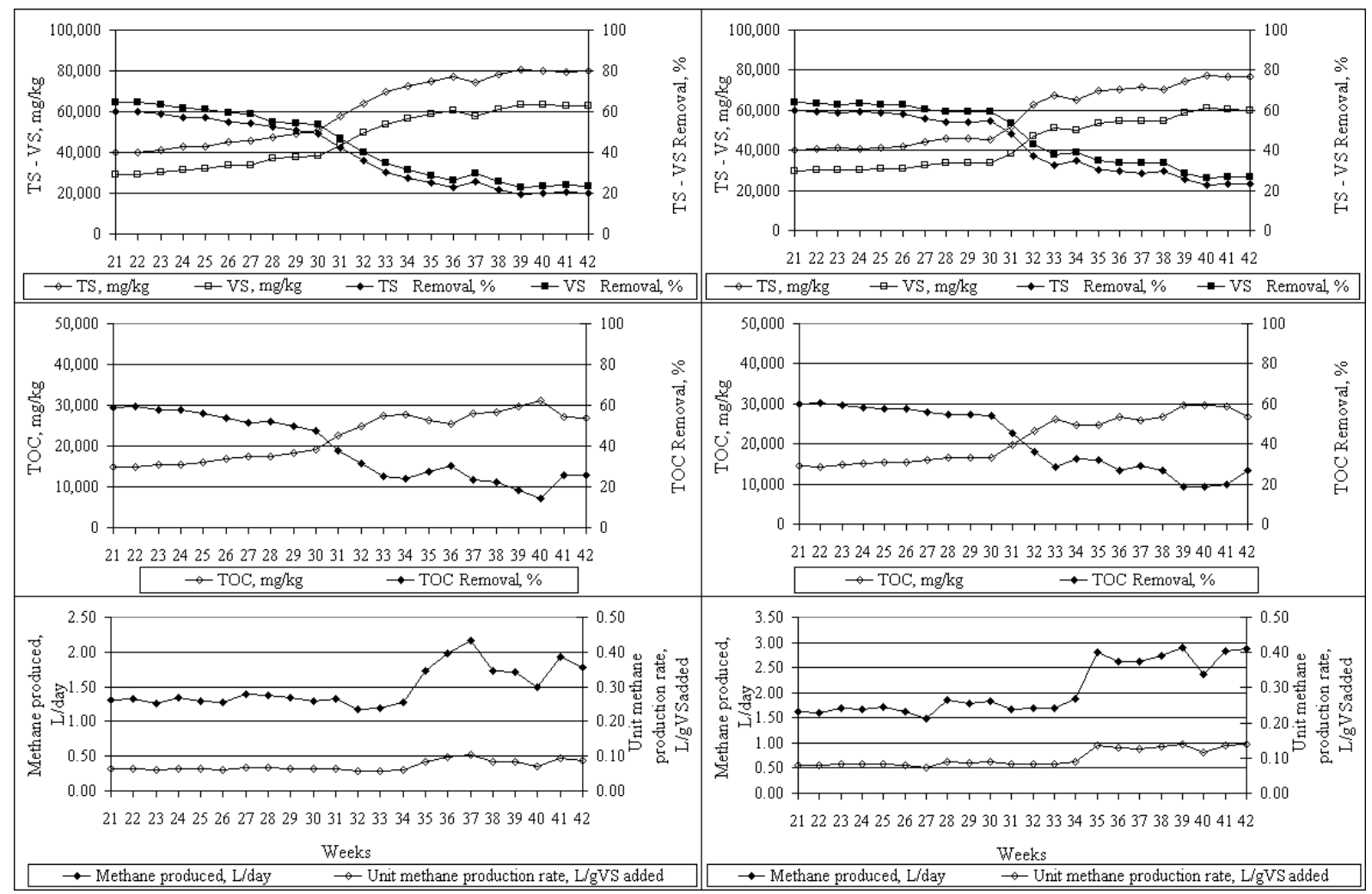

Fig. 3. TS, VS and TOC concentrations in the effluents from mesophilic (A) and thermophilic (B) reactors when only cattle manure of $10 \%$ solids content was fed.

\subsection{Mixture of cattle manure and corn silage feed at $10 \%$ solids content}

In this stage of the study, anaerobic digestion of cattle manure along with corn silage as supplementary organic waste was investigated. In this stage of the study corn silage was added to cattle manure of $10 \%$ solids content and the reactors were operated at an HRT of 40 days. TS, VS, and TOC concentrations of the corn silage were measured as 230,000 $\mathrm{mg} / \mathrm{kg}$, $205,000 \mathrm{mg} / \mathrm{kg}$, and 83,000 $\mathrm{mg} / \mathrm{kg}$, respectively. Those of the mixture of cattle manure and 
corn silage were determined to be $161,600 \mathrm{mg} / \mathrm{kg}, 140,600 \mathrm{mg} / \mathrm{kg}$, and 58,400 mg/kg, respectively. TS, VS, and TOC concentrations measured in the effluents from the reactors are shown in Figure 4.

TS removal efficiencies of the reactors were calculated as around $47.5 \%$ for mesophilic one and around 51.4\% for thermophilic one while VS removal efficiencies were observed as about $53 \%$ and about $59 \%$, respectively. $49 \%$ and $52.4 \%$ of TOC removal efficiencies were obtained for mesophilic and thermophilic reactors, respectively.

After feeding the mixture of cattle manure and corn silage together, the biogas production rate was measured as between 0.16 and $0.37 \mathrm{~L}_{\text {biogas }} / \mathrm{gVS}_{\text {added }}$ for mesophilic reactor and between 0.31 and $0.54 \mathrm{~L}_{\text {biogas }} / \mathrm{gVS}_{\text {added }}$ for thermophilic reactor. For mesophilic and thermophilic reactors, methane production rates were observed to range from 0.08 to $0.19 \mathrm{~L}_{\text {methane }} / \mathrm{gVS}_{\text {added }}$ and from 0.15 to $0.29 \mathrm{~L}_{\text {methane }} / \mathrm{gVS}_{\text {added}}$, respectively.

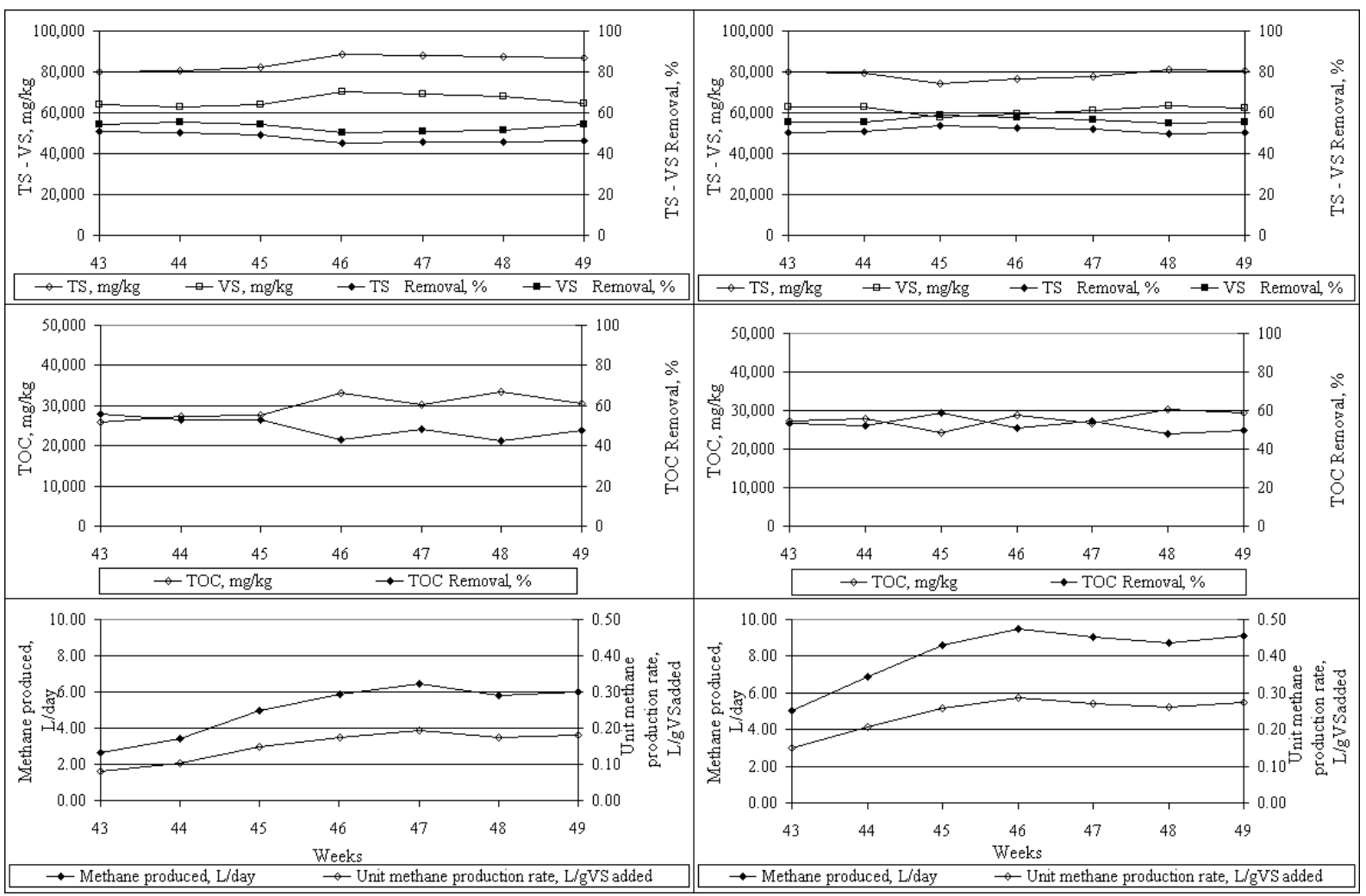

Fig. 4. TS, VS and TOC concentrations in the effluents from mesophilic (A) and thermophilic (B) reactors when a mixture of cattle manure and corn silage of $10 \%$ solids content was fed.

Although the removal efficiency in mesophilic reactor increased considerably by the use of corn silage as a supplementary organic waste, the reactor was still less effective in E.coli removal than thermophilic reactor which completely removed E.coli and Salmonella spp.

\section{Discussion}

The results from the both reactors, which are used to treat cattle manure of $5 \%$ and $10 \%$ solids content anaerobically, suggests that TS, VS, and TOC removal efficiencies as well as biogas and methane production rate per gram VS added were quite similar. The highest removal efficiencies and the highest biogas/methane production rates were obtained in the stage in which cattle manure and corn silage were mixed to obtain $10 \%$ of solids content. The results from this stage were compared to the literature data (Table 2). The results shown in Table 2 
suggest that study results (VS removal efficiency and methane production rate) are satisfactory compared to literature data. Finally, it is necessary to state that the thermophilic reactor was successful in both Salmonella spp. and E.coli removal in stages of the study while mesophilic one was not satisfactory in E.coli removal although it successfully removed Salmonella spp. Related Turkish legislation suggests that Salmonella spp. and E.coli must not be detected in the effluent [5].

Table 2. Comparison of the study results with literature data.

\begin{tabular}{|c|c|c|c|}
\hline Reference & Reactor type & VS removal (\%) & $\begin{array}{l}\text { Methane production } \\
\left.\text { (L } \mathrm{L}_{\text {methane}} / \mathrm{gVS}_{\text {added }}\right)\end{array}$ \\
\hline Current study* & Complete mix & 59 & $0.15-0.29$ \\
\hline [6] & Fill-decant anaerobic & $48-53.6$ & $0.24-0.25$ \\
\hline [7] & Anaerobic hybride & $59-68$ & 0.19 \\
\hline [8] & $\begin{array}{c}\text { Two-phase anaerobic } \\
\text { digester }\end{array}$ & $30.3-62.4$ & $0.07-0.24$ \\
\hline$[9]$ & $\begin{array}{c}\text { Temperature-phased } \\
\text { anaerobic digester (TPAD) }\end{array}$ & $37-41.5$ & $0.15-0.22$ \\
\hline$[10]$ & Complete mix & 28 & 0.20 \\
\hline$[11]$ & $\begin{array}{c}\text { Temperature-phased } \\
\text { anaerobic digester (TPAD) }\end{array}$ & 42.6 & 0.23 \\
\hline [12] & Anaerobic SBR & 22 & $0.07-0.15$ \\
\hline [13] & Complete mix & 38.4 & 0.25 \\
\hline [14] & Fill-decant type & $42-52$ & $0.17-0.22$ \\
\hline [15] & Complete mix & 24.7 & 0.09 \\
\hline
\end{tabular}

*Cattle manure of $10 \%$ solid content mixed with corn silage

\section{Conclusions}

The performance of anaerobic digestion process for the treatment of cattle manure was investigated in this study. The results of the study, in which the effects of different operational temperatures $\left(35^{\circ} \mathrm{C}\right.$ and $55^{\circ} \mathrm{C}$ ), different solids content of the feed ( $5 \%$ and $10 \%$ ), different hydraulic retention times (20 and 40 days) and the addition of corn silage to the feed on the TS and VS removal performances of the reactors and on the biogas production, suggests

- that cattle manure is possible to treat by both feeding alone and feeding mixed with an organic supplementary material (corn silage for the case),

- that the addition of corn silage to the cattle manure increases the treatment efficiency in both reactors,

- that higher VS removal efficiencies and higher methane production were observed if corn silage are provided to the feed,

- that the thermophilic range of operational temperature shows higher performance in the aspects of both methane production and pathogen removal,

- $\quad$ and that cattle manure can be stabilized by anaerobic digestion in an economical and environmentally beneficial way.

Considering all results from the study, it was concluded that thermophilic reactor was satisfactorily effective in pathogen microorganisms removal and VS stabilization. Besides during the stabilization process the use of a supplementary organic material (corn silage) was proven to sustain high energy production potential.

\section{Acknowledgement}

The data presented in this paper was derived from the results of the project 106G026 
financially supported by TUBITTAK under the title of "Public Foundations Research and Development Projects.” The authors would like to thank TUBITAK for financial support.

\section{References}

[1] TUIK(http://tarimsalbilgi.bloggum.com/yazi/tuikden-hayvansal-urunler-tablosu.html)

[2] R.E. Speece, Anaerobik Biotechnology for Industrial Wastewater, Vanderbilt University, 1995, Tennessee.

[3] T. Coşkun, N. Manav, E. Debik, M.S. Binici, C. Tosun, E. Mehmetli, A. Baban, Anaerobic digestion of cattle manure", Sigma Journal of Engineering and Natural Sciences, article in press, in Turkish.

[4] A. Keshtkar, H. Ghaforian, G. Abolhamd and B. Meyssami, Dynamic Simulation of Cyclic Batch Anaerobic Digestion of Cattle Manure, Bioresource Technology 80, 2001, pp. 9-17.

[5] Turkish legislation on production, import, export, supply, and audit of irrigational supplies with organic, organomineral, microbial and enzyme content. Official Print No. 25452 on May 4, 2004, Article 6.

[6] E. Sanchez, R. Borja, P. Weiland, L. Travieso and A. Martin, Effect of temperature and $\mathrm{pH}$ on the kinetics of methane production, organic nitrogen and phosphorus removal in the batch anaerobic digestion process of cattle manure, Bioprocess Eng. 22, 2006, pp. 247-252.

[7] G. Demirer and S. Chen, Anaerobic Digestion of Dairy Manure in a Hybrid Reactor With Biogas Recirculation, World Journal of Microbiology and Biotechnology 21, 2005, pp. 1509-1514.

[8] G. Demirer and S. Chen, Effect of Retention Time and Organic Loading Rate on Anaerobic Acidification and Biogasification of Dairy Manure, Journal of Chemical Technology and Biotechnology 79 (12), 2004, pp. 1381-1387.

[9] A. Sung and H. Santha, Performance of temperature-phased anaerobic digestion (TPAD) system treating dairy cattle wastes, Water Res. 37, 2003, 1628-1636.

[10]B.K. Ahring, A.A. Ibrahim and Z. Mladenovska, Effect of temperature increase from 55 to $65^{\circ} \mathrm{C}$ on performance and microbial population dynamics of an anaerobic reactor treating cattle manure, Wat. Res. 35 (10), 2001, pp. 2446- 2452.

[11]S. Sung and H. Santha, Performance of Temperature-Phased Anaerobic Digestion (TPAD) System Treating Dairy Cattle Wastes, Tamkang Journal of Science and Engineering 4 (4), 2001, 301-310.

[12]P.N. Dugba and R. Zhang, Treatment of Dairy Wastewater with Two-Stage Anaerobic Sequencing Batch Reactor Systems - Thermophilic Versus Mesophilic Operations, Bioresource Tehnology 68 (3), 1999, pp. 225-233.

[13]A. Singh, G. Giridhar, M. Madan and P. Vasudevan, Anaerobic digestion: an appropriate process for integrated utilization of biomass from non-conventional sources, Proc Fifth Int Symp on Anaerobic Digestion, 1988, pp. 943-946.

[14] S.J. Hall, D.L. Hawkes, F.R. Hawkes and A. Thomas, Mesophilic anaerobic digestion of high solids cattle waste in a packed bed digester, J Agr Eng Res 32, 1985, pp.153-162.

[15]D.J. Hills, Methane gas production from dairy manure at high solids concentrations, T. ASAE 23, 1980, pp. 122-126. 